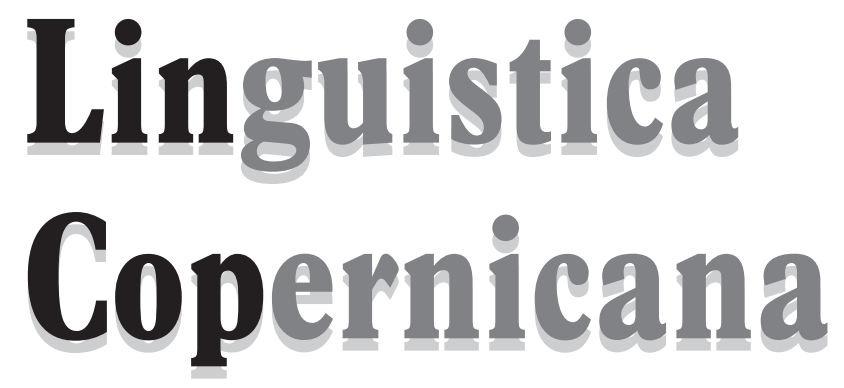

$1(7) / 2012$

WYDAWNICTWO NAUKOWE
UNIWERSytetu MIKOLAJa KOPERNIKA 
REDAKTOR NACZELnY: Maciej Grochowski

Rada Redakcyjna: Ireneusz Bobrowski (Kraków), Andrzej Bogusławski (Warszawa), Gerd Hentschel (Niemcy, Oldenburg), Axel Holvoet (Litwa, Wilno), Krystyna Kleszczowa (Katowice), Roman Laskowski (Kraków), Jarmila Panevová (Czechy, Praha), Jens Nørgård-Sørensen (Dania, Kopenhaga), Zuzanna Topolińska (Macedonia, Skopje), Daniel Weiss (Szwajcaria, Zurich), Anna Wierzbicka (Australia, Canberra)

Kole gi u m R e D K C Y J e: Maciej Grochowski, Krystyna Kallas, Irena Sawicka, Piotr Stalmaszczyk

S E K R ETA R Z R E D A K C I: Iwona Kaproń-Charzyńska

A D R E S R E D A K C J I: Instytut Języka Polskiego UMK, 87-100 Toruń, ul. Fosa Staromiejska 3, e-mail: lincop@umk.pl,www.linguistica.umk.pl

OKŁ A D K A: Monika Pest

(C) Copyright by Wydawnictwo Naukowe Uniwersytetu Mikołaja Kopernika

Toruń 2012

ISSN 2080-1068

Wersją pierwotną (referencyjną) czasopisma jest wersja papierowa.

WYDAWNICTWO NAUKOWE UNIWERSYTETU MIKOEAJA KOPERNIKA

Redakcja: ul. Gagarina 5, 87-100 Toruń

tel. (56) 6114295 , tel./fax 6114705

e-mail: wydawnictwo@umk.pl

Dystrybucja: ul. Reja 25, 87-100 Toruń

tel./fax (56) 61142 38, e-mail: books@umk.pl

www.wydawnictwoumk.pl

Druk: Wydawnictwo Naukowe UMK 
TOMASz NowAK

Uniwersytet Śląski

Instytut Języka Polskiego

\section{Co to jest życie? Preliminaria semantyczne}

Słowa klucze: semantyka, fenomenologia lingwistyczna, czasownik, życie

\section{Wstęp}

Życie, jakie nas otacza (to, w którym bez reszty jesteśmy zanurzeni), wydaje się czymś oczywistym, niemal przezroczystym. Zwykle nie zastanawiamy się nad tym, czym ono jest i jakie jest. Tymczasem ono jest i jako takie stanowi wielką zagadkę (tajemnicę lub wyzwanie), a w każdym razie - pytanie, na które można (bądź nawet trzeba) szukać odpowiedzi: także w języku - nie tylko poza nim. Wierzę w to, że fenomen życia można uchwycić w kategoriach jednostek elementarnych i uniwersalnych (transcendentnych i transcendentalnych), takich, jak czasowniki: wiedzieć i zrobić oraz zaimki: ktoś i coś (najobszerniej na ten temat: Bogusławski 2007). Niniejsza praca ma więc charakter analizy czysto pojęciowej i jako taka mieści się w antynaturalistycznym nurcie fenomenologii lingwistycznej (stanowiąc językoznawczą próbę denaturalizacji osobliwości życia). Przedmiot tej rozprawki stanowią wybrane leksykalne eksponenty pojęcia 'życie', w szczególności zaś - najprostsze $\mathrm{w}$ tej klasie wyrażenie, niezmiennie i powszechnie kojarzone z tym, co stanowi obiekt moich dociekań, mianowicie czasownik żyć. 


\section{Stan badań}

Nie istnieją (ostrożniej: nie są mi znane) prace językoznawcze (teoretyczne i materiałowe), które podejmowałyby (w charakterze głównego przedmiotu rozważań) zagadnienie życia (na materiale współczesnej polszczyzny); nie znalazłem też, poza zaledwie kilkoma wzmiankami, istotniejszych uwag na ten temat. Sporo do powiedzenia o leksykalnych eksponentach pojęcia 'życie' mają za to redaktorzy opracowań leksykograficznych. Problem tkwi jednak w tym, że tytułowe wyrażenie sprawia twórcom słowników niemały kłopot. Chcąc się o tym przekonać, wystarczy sięgnąć do odpowiednich definicji, zaczerpniętych z kilku współczesnych słowników języka polskiego, zob.:

1. USJP: żyć «istnieć w sposób właściwy organizmom żywym - oddychając, odżywiając się, rosnąc itp.; być żywym»;

2. ISJP: Kiedy człowiek, zwierzę lub roślina żyje, to istnieje i funkcjonuje we właściwy dla siebie sposób, np. odżywia się, oddycha, rośnie;

3. SWJP: żyć 'znajdować się w stanie, który wskazuje na nieustanny przebieg biochemicznych procesów przemiany materii i energii $\mathrm{w}$ organizmie, umożliwiających oddychanie, odżywianie, wydalanie $\mathrm{i}$ inne funkcje życiowe; być żywym'.

Słownikarskie próby ujęcia, „życia” w zdyscyplinowane semantycznie ramy definicji nie tylko nie „zauważają” (nie rejestrują) wszystkich jednostek, które wiążą się z pojęciem 'życia' (o czym już za chwilę), ale także (a może właśnie: przede wszystkim) wikłają się nieustannie w liczne błędy (uchybienia i usterki), np.: kolistość i pleonastyczność, zob. USJP: organizm żywy; encyklopedyczność, zob. SWJP: biochemiczne procesy przemiany materii i energii; nadpojemność, zob. ISJP: istnieje i funkcjonuje we właściwy dla siebie sposób; błędna identyfikacja hiperonimu, zob. SWJP: stan, proces.

A jakie stanowisko zajmują w kwestii językowych wykładników pojęcia 'życie' autorzy prac teoretyczno-materiałowych? A. Wierzbicka (2006: 109-111) skłania się ku temu, by pojęcie, jakie wyraża czasownik żyć (z nieodłącznym od niego okolicznikiem czasu), umieścić w zbiorze jednostek uniwersalnych (i nieredukowalnych). Z kolei A. Bogusławski zauważa, że czasownik żyć nie może sytuować się w klasie jednostek elementarnych, gdyż pociąga za sobą m.in. robienie czegoś. Z. Zaron (2009: 89-98), idąc za J. Lyonsem (i polemizując z O. Wojtasiewiczem), definiuje agensa jako istotę 
żywą, świadomą, umyślnie używającą własnego wewnętrznego źródła energii (w kontekście wiedzy i działania).

Nie kryję, że podejmując się analizy semantycznej predykatu żyć, siłą rzeczy zakładam, że mam do czynienia z jednostką podzielną w planie treści na dyskretne komponenty, z których przynajmniej część rokuje szanse (daje nadzieje) na wyodrębnienie ich w toku badań.

\section{Jednostki języka}

Zacznę od rutynowej (dość naturalnej czy w gruncie rzeczy banalnej) obserwacji: otóż ciąg diakrytów (segment tekstowy) żyć pojawia się w bardzo wielu, wzajemnie wykluczających się kontekstach semantycznych (otoczeniach słownych), co może stanowić argument za tym, aby odnotować te wystąpienia jako formalne reprezentacje odrębnych jednostek języka. Oto garść przykładów kontekstów, w jakich pojawia się ciąg żyć (poza zasięgiem analizy pozostawiam nieciagłe jednostki języka, w tym idiomatyczne frazeologizmy i przysłowiowe zwroty):

(1) Kierowca żyje, ale pasażer zginat na miejscu.

(2) Liście opadty, ale drzewo żyje i na wiosnę wypuści nowe liście.

(3) A potem żyli dtugo i szczęśliwie.

(4) Żyt w latach 1632-1677.

(5) Większa część społeczeństwa żyje na wsi.

(6) Żyliśmy skromnie, $w$ domu się nie przelewało.

(7) Od poczatku grudnia dzieci żyja myśla o choince.

(8) Nauczyt się żyć z ludźmi.

(9) Cyganie żyli z kowalstwa, muzykowania po karczmach, niekiedy z przemytu.

(10) Dla siebie nic nie pragnat, żyt tylko dla innych.

Nawet pobieżny przegląd czasownikowych jednostek leksykalnych, zdradzających (choćby tylko formalnie) jakiś związek z pojęciem 'życia', pozwala zaprowadzić w tym obszernym podzbiorze pewien ład. Otóż uważam, że niektóre spośród nasuwających się od razu wyrażeń można od ręki zaklasyfikować jako „biologiczne”, właśnie związane z darem życia, natomiast inne - jako „kulturowe”, związane ze sposobem, w jaki się ów dar, grubo mówiąc, 
pożytkuje, por.: jednostki „biologiczne”: żyć, zob. (1) i (2), oraz jednostki „kulturowe” (m.in.): żyć [ileś], zob. (3)'; żyć [kiedyś], zob. (4); żyć [gdzieś], zob. (5); żyć [jakoś], zob. (6); żyć [czymś], zob. (7); żyć z [kimś], zob. (8); żyć z [czegoś'], zob. (9); żyć dla [kogoś]//[czegoś'], zob. (10).

Naturalnie, przedmiot moich dalszych dociekań będą stanowiły wyłącznie te wyrażenia, w których struktury pojęciowe wpisuje się komponent 'życie’ w swoim najbardziej pierwotnym i źródłowym, właśnie: „biologicznym”, wymiarze.

\section{Analiza semantyczna}

Jako pierwsze nasuwa się (z gruntu pragmatyczne) pytanie o to, w jakich sytuacjach można (fortunnie) użyć czasownika żyć w zajmującym mnie w tej pracy znaczeniu?

Nieco dziwne (trudne do wyobrażenia, a nawet w jakiejś mierze pleonastyczne) wydają się użycia, w których stwierdza się o ludziach, zwierzętach i roślinach, że po prostu żyją (i to bez względu na to, czy orzeka się atrybut życia o całym gatunku, czy o konkretnych osobnikach). Można wręcz odnieść wrażenie, że tego typu wypowiedzenia nie przekazują żadnych nowych informacji, a orzeczniki wprost duplikują treść złożoną w podmiotach (lub daną sytuacyjnie), por. dialogi: przykładowe wypowiedzi i typowe (zasłyszane) reakcje na nie.

(11) dialog

a. A: - (Wiesz) ludzie (zwierzęta, rośliny) żyja.

b. B: - No i co z tego? Żyjq-i już. Tak już ludzie (zwierzęta, rośliny) maja, że zwykle żyja.

(12) dialog

a. A: - (Wiesz) Ten czlowiek żyje. 'o kimś, kto stoi nieopodal'

b. B: - Widzę. I co z tego?

1 Status czasowników: $\dot{z} y c ́$ [ileś], żyć [kiedyś] i żyć [gdzieś] jako jednostek „nie-biologicznych" wydaje się jednak mocno dyskusyjny, zwłaszcza w świetle przykładów typu: Żółwie żyja przeszło sto lat., Dinozaury żyły w czasach prehistorycznych. i Kozice żyja $w$ górach. Przypomnę jedynie, że przedmiot opisu w tej pracy stanowi wyłącznie czasownik żyć (bez uzupełnień temporalnych i lokatywnych). 
Można sobie jednak przedstawić (wyobrazić) sytuację, w której nadawca, formułując te raczej wątpliwej marki teksty, zamierza swojemu interlokutorowi przypomnieć pewne oczywistości (względnie przekazać mu jednak nowe, nieznane wcześniej informacje), nierzadko sytuując je w roli przesłanek wnioskowań, a często - w funkcji implikatur konwersacyjnych.

(13) (Wiesz) Ten człowiek żyje. 'o kimś dawno niewidzianym, z kim coś (złego) się działo (stało)'

(14) ... Wiesz, pies żyje, a komputer - nie. 'zaopiekuj się swoim czworonożnym przyjacielem, bo bardzo cię potrzebuje'

(15) ... Wiesz, zwierzęta i rośliny też żyja. '(więc) szanuj je; troszcz się o nie'

(16) ... Wiesz, ludzie też żyja. 'a nie tylko zwierzęta i rośliny, o które się tak troszczysz'

Z tych kilku zbudowanych na potrzeby analizy, może nieco naciąganych, pragmatycznych scenek wyłania się pewien istotny rys. Otóż nadawcy literalnych wypowiedzi, które fundują ,predykaty witalne”, albo informują swoich odbiorców, że ktoś, z kim coś się stało (zwykle: coś złego), pozostał przy życiu (po prostu, mimo wszystko, nadal żyje), albo przypominają pewne „oczywiste oczywistości”, np. dotyczące znaczeń wyrażeń, mianowicie takie, że świat nasz „zaludniają” (obok realnych rzeczy i zdarzeń) równie realne organizmy, czyli istoty żywe, których egzystencja różni się (jakościowo!) od sposobu, w jaki istnieja przedmioty. Innymi słowy: nadawca albo informuje odbiorcę, że wie o podmiocie, z którym coś się (niedobrego) działo, że ten jest żywy (a nie: że jest nieżywy), albo przypomina odbiorcy, że podmiot jest taki, że z natury swojej jest żywy (a nie: że nie jest żywy). Myślę, że intuicję tę (jako próbę wniknięcia w intencje wirtualnych nadawców) oddają także przykłady:

(17) Ten człowiek (to zwierzę, ta roślina) żyje, a tamten (tamto, tamta) - nie.

(18) Ci ludzie (te zwierzęta, te rośliny) żyja, a tamci (tamte) - nie.

(19) Świat jest tak urzqdzony, że człowiek, zwierzę i roślina żyje, a powietrze, woda i ziemia - nie.

(20) Tak już jest, że ludzie, zwierzęta i rośliny żyja, a krzesła, stoły i szafy-nie. 
Jedno z pierwszych pytań, jakie z kolei w tym miejscu powinny paść, brzmi: o kim albo o czym, mówi nadawca neutralnych wypowiedzi, które zasadzają się na czasowniku żyć? Wiele przemawia za tym, żeby uznać, że temat neutralnych wypowiedzeń, które dźwiga czasownik żyć, stanowi ściśle określony przedmiot: jednostkowy lub zbiorowy, któremu przypisuje się (o którym orzeka się) pewną własność (cechę): aktualną (w wypadku tematu jednostkowego) lub omnitemporalną (w sytuacji, gdy temat kwalifikuje się jako zbiorowy). Wykładnik tematu przyjmuje zatem postać nazwy wziętej w jednej z dwu supozycji normalnych indykacyjnych, mianowicie: w supozycji personalnej lub uniwersalnej (naturalnej, a może nawet i formalnej), tj. jako nazwa: albo osobnika, albo gatunku (wraz ze wszystkimi jego przedstawicielami).

(21) Ten człowiek/to zwierzę/ta roślina ŻYJE (a nie: nie żyje).

(22) Ci ludzie/te zwierzęta/te rośliny ŻYJA (a nie: nie żyja).

(23) Człowiek/zwierzę/roślina ŻYJE (a nie: nie żyje).

(24) Ludzie/zwierzęta/rośliny ŻYJA (a nie: nie żyja).

Na podstawie poczynionych obserwacji wysuwam hipotezę, że w klasie werbalnych jednostek języka z segmentem żyć (w podklasie jednostek leksykalnych, które wnoszą znaczenia, jakie roboczo określiłem jako „biologiczne", czyli bezpośrednio związane z 'darem życia'), można wyodrębnić co najmniej dwa elementy - czasowniki właściwe: $\dot{z} y c_{1}$ i $\dot{z} y c_{2}$, którym przysługują (wszystko na to wskazuje) różne właściwości semantyczne, np. ze względu na: typ tematu (w STR wypowiedzi) i rodzaj argumentu (w SPA zdania).

Czasowniki: $\dot{z} y c_{1}$ i $\dot{z} y c_{2}$ organizują wypowiedzenia neutralne, których temat stanowi: albo przedmiot jednostkowy, por. $\dot{z} y c_{1}$, albo przedmiot zbiorowy, por. $\dot{z} y c_{2}$. Czasownik $\dot{z} y c_{1}$ (z nazwą agensa wziętą w supozycji personalnej) jest osnową (negabilnych) zdań syntetycznych a posteriori, z kolei czasownik $\dot{z} y c_{2}$ (z nazwą agensa w supozycji uniwersalnej) stanowi zrąb (nienegabilnych) zdań analitycznych a priori. Co się z tym wiąże, wypowiedzi, które tworzy czasownik $\dot{z} y c_{1}$, pełnią (głównie) funkcje informacyjne (np. funkcję konstatacji), natomiast wypowiedzi, które zasadzają się na czasowniku $\dot{z} y c_{2}$, pełnią, jak mniemam, niemal wyłącznie funkcje pozainformacyjne (funkcję 
metajęzykową) $)^{2}$. Ponadto, czasowniki: $\dot{z} y c_{1}$ i $\dot{z} y c_{2}$ pozostają względem siebie w takim stosunku, iż aktualne znaczenie leksemu $\dot{z} y c_{1}$ implikuje (na zasadzie hiponimii) omnitemporalne znaczenie leksemu $\dot{z} y c_{2}$. Jednostka $\dot{z} y c_{1}$ specjalizuje się przy tym w wyrażaniu relacji między członami opozycji: 'życie' - 'śmierć', zaś jednostka $\dot{z} y c_{2}$ stanowi formalny wykładnik opozycji między pojęciami: 'życie' - 'nie-życie'3. Predykaty te (być może operanda operacji semantycznych) sygnowałyby zatem odrębne, pozostające względem siebie w relacji inkluzji treści, które (w wielkim przybliżeniu) oddają robocze parafrazy: 'ktoś pozostał przy życiu (o kimś, kto istnieje realnie, z kim coś się stało)' i 'ktoś jest obdarowany życiem (o kimś, kto istnieje realnie)'.

Czasowniki: $\dot{z} y c_{1}$ i $\dot{z} y c_{2}$ pozostają ze sobą w ścisłych relacjach, w związku z czym będę je dalej omawiał we wzajemnym odniesieniu.

Jako kolejne samorzutnie nasuwa się pytanie o to, kto (lub: co) nadaje się na podmiot $\mathrm{w}$ zdaniach minimalnych $\mathrm{z}$ czasownikami: $\dot{z} y c_{1}$ i $\dot{z} y c_{2}$; ściślej rzecz biorąc, idzie tu o nazwy bytów, które mogą zająć w zdaniach z czasownikami: $\dot{z} y c_{1}$ i $\dot{z} y c_{2}$ pozycję syntaktyczną, której przypisuje się rolę agensa.

Po pierwsze, uważam, że ,predykaty witalne” można orzekać jedynie o tych elementach-częściach rzeczywistości, które zgodnie (w każdym razie: przeważnie) podpadają pod zaimek ktoś (co wyklucza w pozycji agensa - w zdaniach z czasownikami: $\dot{z} y c_{1}$ i $\dot{z} y c_{2}$ - ogół rzeczy i zdarzeń, ale też uniwersum: czynności, procesów i stanów, które odsyłają wprost do zakresu zaimka coś, por. kształty jednostek języka: [ktoś] żyje, nie: [coś] żyje).

(25) *To coś (nie) żyje., ale: Oo! To coś jakby (nie) żyje./To coś (nie) „żyje”.

(26) Ten ktoś (nie) żyje., ale: *Oo! Ten ktoś jakby (nie) żyje./*Ten ktoś (nie) ,żyje”.

Warto zauważyć, że bez względu na to, czy ktoś (jeszcze) żyje, czy (już) nie, „od zawsze” i „do zawsze” pozostaje „kimś”.

${ }^{2}$ Niektórzy językoznawcy funkcję metajęzykową kwalifikują jako funkcję informującą (o pewnych atrybutach języka i mowy).

3 Opozycję 'życie' - 'nie-życie' oddaje również para wyrażeń: być żywym - nie być $\dot{z} y w y m$, natomiast opozycję 'życie' - 'śmierć' - para wyrażeń: być żywym - być nieżywym, por. też: $\dot{z} y j a c y$ - nieżyjacy. Naturalnie, opozycja 'życie' - 'śmierć' zachodzi jedynie w obrębie pierwszego członu opozycji 'życie' - 'nieżycie'. 
(27) dialog

a. A: - Kto żyje?/Kto przeżyt?

b. B:-Adam (żyje). 'o kimś'

(28) dialog

a. A: - Kto nie żyje?/Kto nie przeżyt?

b. B:-Adam (nie żyje). 'o kimś'

Chciałoby się więc rzec, że osobowość przynosimy na świat i ze świata ją wynosimy: jest nam zatem przypisana raz na zawsze. „Predykaty witalne”, powtórzę jeszcze raz z naciskiem, odnoszą się do świata podmiotów, a nie przedmiotów, np. do osób, a nie - do ich ciał; co ilustruje, w moim odczuciu, para zdań: (29) i (30):

(29) *Nieżywy Adam myśli o Ewie. 'o osobie Adama'

(30) Nieżywy Adam leży na podłodze. 'o ciele Adama'

W związku z tym, nie można również cechy życia przypisywać fragmentom czyjegoś ciała - nawet tak dalece złożonym (zdawałoby się: zaawansowanym i względnie autonomicznym) jak ludzki mózg ${ }^{4}$.

(31) *Ciało Adama (nie) żyje.

(32) *Mózg Adama (nie) żyje.

Po drugie, przypuszczam, że czasownik żyć można orzec tylko o tych bytach, które istnieją realnie; innymi słowy: zajmujący mnie predykat nie łączy się z nazwami bytów: absolutnych i idealnych, ale także z nazwami bytów czysto intencjonalnych i myślnych.

(33) *Bóg (nie) żyje., ale: Bóg (nie) istnieje.

(34) *Prawda/dobro/piękno (nie) żyje., ale: Prawda/dobro/piękno (nie) istnieje.

(35) *Krasnoludki (nie) żyja., ale: Krasnoludki (nie) istnieja.

4 Wypowiedzi te wydają się mocno nienaturalne - jakkolwiek pojawiają się w profesjolekcie lekarskim; można by rzec, że do jakiegoś stopnia już się użytkownikom języka „osłuchały”, przez co wydają się zwodniczo gładkie. 
Dlaczego o Bogu, ideach (prawdy, dobra, piękna) i krasnoludkach, z jednej strony, a także o Bogu i rzeczach (ale też zdarzeniach, czynnościach, procesach i stanach), z drugiej strony, nie można orzec, że żyją, względnie: nie żyją (są żywi/żywe lub nieżywi/nieżywe)? Po pierwsze, Bóg (jako byt absolutny), a także prawda, dobro i piękno (jako byty idealne) oraz krasnoludek (jako byt myślny) nie istnieją w czasie. Po drugie, Bóg (jako byt absolutny) wie wszystko, a także wszystko może (robić), z kolei rzecz (jako byt realny, ale pozbawiony ,tchnienia”) nic nie wie oraz nic nie robi. Innymi słowy (do czego jeszcze wrócę), życie sytuuje się jak gdyby w temporalnej dziedzinie aktywnych (samych z siebie) i samowiednych (samych przez się) bytów między osobą Boga a światem rzeczy.

Reasumując: twierdzę, że czasownik żyć można orzekać wyłącznie o organizmach, czyli o takich bytach, które (zarazem) wchodzą w obręb zakresu zaimka ktoś oraz istnieją realnie, tj. o ludziach, zwierzętach i roślinach ${ }^{5}$ (co pokrywa się z intuicją - teraz jednak ujętą krytycznie, nie - naiwnie). W tej sytuacji wyłania się jednak kolejna wątpliwość? Cóż to jednak znaczy istnieć realnie (i czy w tym terminie nie kryje się przypadkiem pleonazm)?

Byty realne, na mocy definicji, istnieją. Co znamienne, czasownik istnieć, w sytuacji, gdy wiąże się z nazwą istoty żywej, znaczy dokładnie tyle, co czasownik $\dot{z} y c ́$ (w wypadku, kiedy predykaty te, istnieć i $\dot{z} y c ́$, orzekamy o istotach żywych, idą one niejako ,ramię w ramię", warunkując się wzajemnie).

(36) *Adam nie żyje, ale istnieje. oraz *Adam nie istnieje, ale żyje.

(37) Ktoś taki nigdy nie istniat. $=$ Ktoś taki nigdy nie żyt.

Życia nie sposób przeto sprowadzić do nadrzędnej ontycznie kategorii istnienia: gdy bowiem mówię o organizmie, że istnieje, to mówię tym samym, że żyje (i odwrotnie).

Byty realne, co zresztą je wyróżnia w zbiorze pozostałych bytów (absolutnych, idealnych i intencjonalnych), mają charakter ściśle temporalny (czasowy): posiadają bowiem na osi czasu swój wyraźny początek oraz koniec (w opozycji do bytu absolutnego, idealnego i intencjonalnego); tylko do nich stosują się zatem pytania o wyrażane w jednostkach czasu granice istnienia:

5 Przekonujące (moim zdaniem) dowody na rzecz tezy, że zwierzęta i rośliny wchodzą w zakres zaimka ktoś, podaje Z. Zaron, zob. Zaron 1998 i 2011. 
(38) Jak dtugo (od kiedy i do kiedy) żyt/żyje/będzie żyt (ten) człowiek?

(39) 'Jak dtugo (od kiedy i do kiedy) istniat/istnieje/będzie istnieć Bóg?

(40) 'Jak dtugo (od kiedy i do kiedy) istniaty/istnieja/będa istnieć krasnoludki?

Przypuszczam również, że ,predykaty witalne” ( $\dot{z} y c_{1}$ i $\left.\dot{z} y c_{2}\right)$, nazywają pewną cechę (sposób istnienia: najpierw - omnitemporalny, a następnie - aktualny), która przysługuje podmiotowi od momentu jego poczęcia (a więc nie od chwili przyjścia na świat, czyli narodzin) do jego śmierci ${ }^{6}$. Intuicję tę można, jak sądzę, wyczytać z semantycznie uwarunkowanych, a syntaktycznie zaangażowanych postaci jednostek języka.

(41) [ktoś] począ [kogoś 2 , np. poczać dziecko, nie: *poczać zarodek (embrion)

(42) [ktoś] ] spłodzit [kogoś 2 , np. spłodzić syna/córkę, nie: *spłodzić zarodek/płód

(43) [ktoś] urodzit [kogośs], np. urodzić dziecko, nie: *urodzić płód

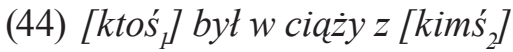

a. matka Ewy: Kiedy bytam w ciaży z Ewa, to...

b. matka Ewy: *Kiedy byłam w ciązy z Ewa, która jeszcze wtedy nie była Ewa, to..., wobec: Kiedy byłam w ciqży z Ewq, która jeszcze wtedy nie byta ,Ewa”, to...

O tym, kto żyje, a kto - nie, można się dowiedzieć wprost, np. obserwując, czy dana nazwa łączy się z predykatami typu $\dot{z} y c_{1}$ czy $\dot{z} y c_{2}$. W niektórych sytuacjach o kwalifikacji bytu - jako istnienia, któremu przysługuje atrybut życia - decyduje jednak dyskurs apofatyczny. Jeżeli bowiem nie sposób literalnie orzec o kimś, że żyje (z różnych, zwykle: ,pozasemantycznych” względów, np. stylistycznych), należy spróbować odnieść do niego predykat, który w swoim znaczeniu mieści sens zgoła przeciwstawny. Dowód apagogiczny sprowadza się więc do tego, że jeśli o kimś można orzec, że umarł (sięgając po różne tego sensu leksykalne eksponenty, w tym zróżnicowane hiponimy), to znaczy, że żył.

${ }^{6}$ Warte przemyślenia wydają się (zwłaszcza w tym kontekście) pytania typu Jak długo żyje/żyt? lub Ile żyt?, uwzględniające okres od urodzenia śmierci, a także zapewnienia w rodzaju Jak dtugo żyję, niczego takiego nie widziałem. 
(45) Ten człowiek umart $\{\ldots\}$... $\rightarrow$ Ten człowiek żyt.

a. Ten noworodek/to niemowlę zmarto.

b. Ten zarodek/płód obumart.

(46) To zwierzę zdechło \{...\}. $\rightarrow$ To zwierzę żyło.

(47) Ta roślina uschta $\{\ldots\}$... $\rightarrow$ Ta roślina żyła.

Nie sposób, w związku z tym, nie przystać na interpretację, w myśl której jednostkowe życie jest w stosunku do śmierci komplementarne; podpowiadają to zresztą najprostsze zestawienia:

(48) *Adam zarazem żyje i nie żyje.

(49) Jeśli Adam żyje, to nieprawda, że nie żyje, a jeśli Adam nie żyje, to nieprawda, że żyje.

Można nawet wskazać w tym względzie tzw. „wyjątki, które potwierdzają regułę":

(50) Chrystus zmartwychwstał., ale: *Żyjacy Chrystus zmartwychwstat.

(51) Jezus wskrzesit Łazarza., ale: *Jezus wskrzesit żywego Łazarza.

Przypomnę, że o ile w wypowiedziach z czasownikiem $\dot{z} y c_{1}$ dochodzi do głosu relacja 'życie' - 'śmierć', o tyle w wypowiedziach z czasownikiem $\dot{z} y c_{2}$ zarysowuje się wyraźnie opozycja 'życie' - 'nie-życie'. O organizmach (o ludziach, zwierzętach i roślinach) można zatem orzec (omnitemporalnie), że żyją, względnie (aktualnie), że albo żyją (są żywe), albo nie żyją (są nieżywe), używając $\mathrm{w}$ tym celu przewidzianych dla poszczególnych podzbiorów stosownych hiponimów. Z kolei o rzeczach (np. o krzesłach, stołach i szafach), ale również o absolutnym Bogu i intencjonalnych krasnoludkach nie można wprost zawyrokować, że są nieżywe, lecz jedynie: że nie są żywe.

(52) *Ludzie (zwierzęta, rośliny) nie sa (w ogóle) żywi (żywe).

(53) *Ci ludzie (te zwierzęta, te rośliny) nie sq żywi (żywe).

(54) Krzesta (stoły, szafy) nie sa żywe.

(55) *Ludzie (zwierzęta, rośliny) sq (w ogóle) nieżywi (nieżywe)., wobec: Ci ludzie (te zwierzęta, te rośliny) sq nieżywi (nieżywe).

(56) *Krzesta (stoty, szafy) sq nieżywe. 
Interesująco $\mathrm{w}$ tym kontekście przedstawiają się collectiva $\mathrm{w}$ rodzaju: ludzkość, przyroda oraz roślinność, które jako „byty wieczne” (w perspektywie znikomej ludzkiej egzystencji) mogą się odradzać (taki ontologiczny recykling nie zachodzi w wypadku konkretnych osobników).

(57) Ludzkośćlprzyroda (fauna)/roślinność (flora) się odradza.

(58) *Ten człowiek/to zwierzę/ta roślina się odradza.

(59) *Ludzie/zwierzęta/rośliny się odradzaja.

Z przeprowadzonych analiz wyłania się skromny, ale względnie jasny obraz: organizm to ktoś, kto żyje, czyli ktoś, kto m.in. istnieje realnie, a więc w czasie, tj. od swojego naturalnego początku do swojego naturalnego końca. Atrybut ten, jakkolwiek funduje dictum tematyczne odpowiedniej paralokucji, nie wyczerpuje jednak całego bogactwa sensów, jakie niosą wraz z sobą „predykaty witalne”. W celu dotarcia do składników, które w dictum rematycznym będą pełniły rolę differentia specifica, przyjrzę się nieco bliżej relacjom, w jakich pozostają do siebie takie wielkości, jak życie oraz m.in. wiedza i działanie.

„Predykaty witalne”, tj. czasowniki: (aktualny) żyć i (omnitemporalny) $\dot{z} y c_{2}$, odznaczają się szeregiem interesujących właściwości semantycznych, które bezpośrednio przekładają się na atrybuty życia (w jego najbardziej pierwotnym i źródłowym sensie). Przedmiot dalszych analiz będzie stanowić przede wszystkim znaczenie czasownika omnitemporalnego: $\dot{z} y c_{2}$, w tym stosunki, w jakich pozostaje do innych elementów systemu (m.in. do swego aktualnego partnera: $\left.\dot{z} y c_{1}\right)$.

Po pierwsze, przypuszczam, że czasownik żyć nazywa cechę, jaką odznacza się pewna klasa bytów (organizmów) - w żadnym zaś wypadku: zdarzenie, względnie: czynność, proces lub stan. Sądzę, że sugestia ta wyłania się z przykładowych dialogów, które unaoczniają to, że wypowiedzi z udziałem eksplikowanej jednostki nie nadają się jako odpowiedzi na pytania o czynności, procesy i stany.

(60) dialog

a. A: - Co ludzie/zwierzęta/rośliny (teraz, zwykle, zawsze) robia?

b. B: - *Ludzie/zwierzęta/rośliny (teraz, zwykle, zawsze) żyja. 
(61) dialog

a. A: - Co się z ludźmi/zwierzętami/roślinami (teraz, zwykle, zawsze) dzieje?

b. B: - *Ludzie/zwierzęta/rośliny (teraz, zwykle, zawsze) żyja.

(62) dialog

a. A: - W jakim ludzie/zwierzęta/rośliny sq (teraz, zwykle, zawsze) stanie?

b. B: - *Ludzie/zwierzęta/rośliny (teraz, zwykle, zawsze) żyja.

(63) dialog

a. A: - Co wiesz o ludziach/zwierzętach/roślinach?

b. B: - Wiem, że ludzie/zwierzęta/rośliny żyja (= sq żywi/żywe) (w przeciwieństwie do $n p$. krzeset/stołów/szaf).

(64) dialog

a. A: - Jacy/jakie ludzie/zwierzęta/rośliny sq (w przeciwieństwie do $n p$. krzeset/stołów/szaf)?

b. B: - (W przeciwieństwie do np. krzeset/stołów/szaf) ludzie/zwierzęta/rośliny żyja (= sq żywi/żywe).

Po drugie, sądzę, że istnieją argumenty na rzecz tego, aby uznać, że czasownik $\dot{z} y c_{2}$ może orzec o pewnym podmiocie wyłącznie różny od niego nadawca; innymi słowy: być może jest tak, iż nie można samemu o sobie orzec ani tego, że się żyje, ani (zwłaszcza) tego, że się nie żyje - wiedzieć to (i, co za tym idzie, orzekać o tym) może jedynie nadawca wypowiedzenia jako pewien bezstronny obserwator (w przeciwnym razie wypowiedź staje się pleonastyczna lub grzęźnie w nieuchronnych sprzecznościach):

(65) *(Nie) Żyję. ${ }^{7} \rightarrow *$ Wiem, że (nie) żyję.

a. *Wiem, że żyje. $\rightarrow$ *Wiem, że wiem, że...

7 Oczywiście, można samemu o sobie orzec, że się żyje, np. gdy odzyskuje się przytomność po wypadku i z niedowierzaniem stwierdza się: Żyję! Mam jednak pewne wątpliwości co do tego, czy wypowiedzi tego rodzaju są wygłaszane „na serio”, czy jedynie żartobliwie. 
b. *Wiem, że nie żyję. $\rightarrow$ *Żyje ktoś, kto nie żyje. ( $\rightarrow$ *Istnieje ktoś, kto nie istnieje.)

Uwagę przykuwają wypowiedzenia, których nadawca (i podmiot - w jednej osobie) stwierdza o sobie samym, że nie żyje, względnie orzeka o adresacie swojej wypowiedzi (podobnie jak poprzednio: w roli agensa), że ten jest martwy.

(66) (Wiem o sobie, $\dot{z} e) \mathrm{Ja} *(n i e) \dot{z} y j e ̨$.

(67) (Wiem o tobie, $\dot{z} e$ ) Ty *(nie) żyjesz.

(68) (Wiem o nim, że) On (nie) żyje.

(69) *Adam wie (o mnie), że (ja) nie żyję.

(70) *Adam wie (o tobie), $\dot{z} e$ (ty) nie żyjesz.

(71) *Adam wie (o sobie), $\dot{z} e$ (on) nie żyje.

Nadawca i odbiorca wypowiedzi (czyli ja i ty) są (z konieczności) aktualnie, tj. w momencie mówienia i słuchania, żywi. W związku z tym, nie mogą powołać do istnienia wypowiedzeń, w których występują w roli agensa i adresata jako osoby martwe. Wiąże się to ze szczególną natura ,predykatów witalnych". Otóż czasownik żyć ma charakter autopoietyczny, co znaczy, że gdy nadawca wypowiada frazę: Ja żyję., to czyniąc to, daje zarazem tego dowód, por. także frazę: Ja mówię.

Po trzecie, domniemywam, że między życiem a wiedzą i aktywnością organizmów istnieją istotne i nierozerwalne więzi. Być może żyć to (mniej więcej) tyle, co coś wiedzieć i coś robić - w dodatku stale i nieprzerwanie (od chwili poczęcia aż do momentu zgonu). Myślę, że przeczucie to podbudowują następujące przykłady:

(72) *Adam coś robi i zarazem nie żyje.

(73) *Adam coś wie i zarazem nie żyje.

(74) *Adam to wie/robi. 'o kimś martwym'

(75) Adam to wie/robi. 'o kimś nieprzytomnym'

Nie sposób się w tym miejscu zgodzić z teorematem, jaki wysuwa A. Wierzbicka (2006: 109-111), zgodnie z którym życie (jako takie) pociąga za sobą (zaledwie!) możliwość działania i wiedzy. Jeżeli bowiem, zgod- 
nie $\mathrm{z}$ tym tokiem myślenia, ktoś może coś robić (i coś wiedzieć), to równie dobrze może nic nie robić (i nic nie wiedzieć) - a tę ewentualność powyżej wykluczyłem. Co interesujące (a jednocześnie, w moim przekonaniu, potwierdzające wysuniętą hipotezę), życie wyklucza zarówno wszechwiedzę i wszechmoc (definicyjne atrybuty Boga), jak również brak jakiejkolwiek wiedzy i aktywności (co z kolei charakteryzuje świat rzeczy i zdarzeń). O kim zatem można orzec, że (tylko i aż) coś wie i coś robi? Moim zdaniem, jedynie o organizmach, które (w przeciwieństwie do Boga i rzeczy) coś wiedzą i coś robią (dokładnie tyle: ani więcej, ani mniej). Nie sposób również przystać na podporządkowanie sensu, jaki wnoszą ,,predykaty witalne”, temu, co kryje się w zawartości pojęciowej czasownika czuć: wszak czucie pociąga za sobą wiedzę, stanowiąc coś na kształt jej alloleksu, por. jeśli ktoś coś czuje, to właśnie to wie, a ponadto wie o tym czymś, że jest to dla niego pod pewnym względem dobre lub złe (naturalnie, wiedzy nie można utożsamiać z czuciem!).

Po czwarte, dane językowe - tak, jak ja je interpretuję - przemawiają wreszcie (i ten wątek pragnę na koniec wyeksponować) za jednorazowym i nieprzerwanym, ale także jednorodnym i nieodwracalnym charakterem biegu życia.

(76) *(Ten) człowiek już kilka razy (nie) żyt.

(77) *(Ten) człowiek od czasu do czasu (nie) żyje.

(78) *(Ten) człowiek czasami żyje, a czasami - nie.

(79) *(Ten) człowiek częściowo żyje, a częściowo - nie.

(80) *(Ten) czlowiek trochę (nie) żyje.

(81) *(Ten) człowiek coraz bardziej/mniej (nie) żyje.

(82) *(Ten) czlowiek już żyje., wobec: (Ten) człowiek już nie żyje.

(83) *(Ten) człowiek jeszcze nie żyje., wobec: (Ten) człowiek jeszcze żyje.

Sądzę, że skonstruowane na potrzeby analizy przykłady można interpretować jako dowody na rzecz tezy, że wiedza i aktywność istot żywych (organizmów) to atrybuty, które przysługują im permanentnie - od momentu poczęcia aż do chwili śmierci, a co za tym idzie - nie istnieje w strumieniu życia jakaś nieciągłość: żyjąc, nieprzerwanie coś wiemy i robimy (nawet je- 
żeli jesteśmy zupełnie sparaliżowani względnie niezdolni w tym momencie do przeprowadzania jakichkolwiek operacji mentalnych ${ }^{8}$.

Najważniejsze właściwości znaczeniowe czasownika omnitemporalnego żyć odnotowuję w postaci wstępnej paralokucji, uwzględniając zarazem ich status jako komponentów diktalnych lub rematycznych. Zaproponowana definicja ma na celu bardziej uporządkowanie rozważań (i prezentację wyników pewnego etapu analizy) niż wierną i kompletną reprezentację znaczenia eksplikowanego wyrażenia.

\section{[ktoś] żyje \\ [temat] ktoś,}

[dictum tematyczne] kto istnieje w $t_{1}-t_{\mathrm{n}}$,

[remat] jest taki, że istnieje ktoś ktoś coś wie i coś robi (= nieprawda, że ktośa wszystko wie i wszystko może, oraz nieprawda, że ktoś nic nie wie i nic nie robi), przy czym nieprawda, że istnieje takie $t_{\mathrm{i}} \in t_{1}-t_{\mathrm{n}}$, że $t_{\mathrm{i}}$ ktoś ${ }_{\mathrm{a}}$ nic nie wie i nic nie robi.

\section{Zakończenie}

Niniejszy szkic nie jest ani przemyślany w całości, ani domyślany w szczegółach - stanowi owoc ledwie kilkutygodniowych przymiarek. Na podstawie przeprowadzonych analiz mogę jednak pokusić się o pewne uogólnienia. Otóż język, a taki m.in. obraz wyłania się z mowy, z natury rzeczy zaludniają obiekty żywe. Życie stanowi część naszego naturalnego nastawienia: milcząco przyjęte założenie, wiecznie obecną presupozycję oraz głęboko ukryty entymemat. Życie traci swą oczywistość (staje się zauważalne) w sytuacjach egzystencjalnie granicznych: albo gdy jest zagrożone (w skali jednostki), albo kiedy jest przeciwstawiane temu, co nim nie jest (w skali ponadjednostkowej). Wyraźnie daje tu więc o sobie znać pewna widoczna gołym okiem asymetria: w zasadzie mówimy o życiu tylko wtedy, kiedy możemy je zestawić z jego brakiem.

${ }^{8}$ Można to też udowodnić, sięgając do semantycznych właściwości predykatu robić coś, który jest nienegabilny w tym tego słowa znaczeniu, że negacja nie ima się samego predykatu, lecz jedynie różnicującego specyfikę czynności elementu coś, por. także w charakterze dowodu logiczne prawo kontrapozycji: $S a P \rightarrow P^{\prime} a S^{\prime}$. 


\section{Bibliografia}

BogusŁawski A., 1976, O zasadach rejestracji jednostek języka, Poradnik Językowy, z. 8 , s. 356-364.

BogusŁawski A., 1977, Problems of the Thematic-Rhematic Structure of Sentences, Warszawa: PWN.

BogusŁawski A., 1983, Interpretacja nieliteralna, metafora, proporcja analogiczna, w: M. Głowiński, A. Okopień-Sławińska (red.), Studia o metaforze II, Wrocław: Ossolineum, s. 63-88.

BogusŁawski A., 1996a, Logiczne, nielogiczne, pozalogiczne, Przeglad Humanistyczny 5, s. 109-142.

BogusŁawski A., 1996b, Świętość jakości życia?, Przeglad Humanistyczny 40/2, s. 1-38.

BogusŁawski A., 1997, Do świata przez język, Przeglad Humanistyczny 2, s. 103-129.

BogusŁawski A., 2001, O pozytywnej stronie granic poznania, w: A. Horecka, J. Jadacki (red.), U progu trzeciego tysiqclecia. Człowiek - Nauka - Wiara, Warszawa: Wydawnictwo Naukowe Semper s. 209-245.

BogusŁawski A., 2002, Światopogląd i wiedza (glosa do pewnej dyskusji), Przeglad Humanistyczny 46, 2 (371), s. 1-30.

BogusŁawski A., 2004, Rezygnacja i nadzieja filozofów, Przeglad Humanistyczny, nr 383, s. 1-26.

Bogustawski A., 2007, A Study in the Linguistics-Philosophy Interface, Warszawa: BEL Studio.

Duraj-Nowosielska I., 2007, Robić coś i coś powodować. Opozycja agentywności i kauzatywności w języku polskim. Warszawa: Wydz. Polonistyki UW.

ISJP: Bańko M. (red.), 2000: Inny stownik języka polskiego, t. 1-2. Warszawa: Państwowe Wydawnictwo Naukowe.

NKJP: Narodowy Korpus Języka Polskiego, http://nkjp.pl [online].

NowaK T., 2012a, Opozycja „czlowiek (umyst) - maszyna (komputer)” w języku. Głos językoznawczy w dyskusji nad sztucznq inteligencja [w druku].

Spaemann R., 2001, Osoby. O różnicy między czymś a kimś. Tłum. J. Merecki SDS. Warszawa: Granice.

StępIeń A. B., 1995, Wstęp do filozofii. Lublin: TN KUL.

SWJP: Dunaj B. (red.), 1996, Stownik wspótczesnego języka polskiego, Warszawa: Wydawnictwo Wilga.

USJP: Dubisz S., (red.), 2003, Uniwersalny stownik języka polskiego, t. 1-6. Warszawa: Wydawnictwo Naukowe PWN.

Wierzbicka A., 2006: Semantyka. Jednostki elementarne $i$ uniwersalne, przekł. A. Głaz., K. Korżyk, R. Tokarski, Lublin: UMCS. 
Zaron Z., 1998, Czy zwierzę to ktoś? Językowe dowody podmiotowości zwierząt, Prace Filologiczne, t. 43, s. 507-515.

ZARon Z., 2001, Obraz Boga językiem narysowany. Orzecznikowe dystynkcje pojęcia „Bóg”, Studia Slavica Oldenburgensia, s. 449-459.

ZARon Z., 2009: Problemy składni funkcjonalnej, Warszawa: Wydawnictwo Wydziału Polonistyki UW oraz BEL Studio.

Zaron Z., 2011, Ktoś to znaczy kto? O językowym statusie roślin, Poradnik Językowy, z. 1, s. 121-130.

\section{What is life? Semantic Preliminaries}

( su m mary)

The term used in the title has not so far been the subject of a more extensive linguistic reflection. The author of the paper aims at providing a disciplined description of lexical units containing the segment $\dot{z} y c \dot{c}$ with respect to their structure and meaning. The method of analysis is based on putting forward hypotheses in the form of analytical implications and subjecting them to falsification by bringing them down to contradiction. The content of the paper focuses on issues relating to reconstruction of the form of lexical units (on the basis of segment and supra-segment signals) and reconstruction of the hierarchy of meaningful components. In close relationship with the content of the analysed terms, also the notions wiedzieć ('to know') and robić ('to do/make') are discussed. The author tries to prove that those components belong to the semantic structure of the examined phrase; he also proposes a preliminary explication of meanings in the terms of natural semantic meta-language. 